\title{
Introduction: The Rise and Puzzling Fall of the Swedish Educational System
}

\section{The Miracle}

In the half-century before 1914, Sweden experienced an extraordinary economic surge that was sustained over nearly a hundred years. Due to a long-term rate of growth surpassing that of virtually all other nations, the country spectacularly transformed itself from an impoverished agrarian society-indeed, one of the poorest in Europe-to one of the richest and technologically most advanced industrialized countries in the world. ${ }^{1}$ All Swedish citizens, including those belonging to the lower social classes, enjoyed the fruits of this extremely rapid economic progress in terms of a significantly improved standard of living. ${ }^{2}$

What prompted this miraculous turnaround? According to the economic historian Lars G. Sandberg, Sweden's takeoff during the second half of the 1800s would not have been possible without a high-quality system of schooling. Sandberg writes, "Mid-nineteenth century Sweden had a strikingly large stock of human and institutional capital. ... Sweden was a poor but sophisticated country." 3

Literacy was common as early as the late 1600s, in no small part because Swedish Lutheran priests were responsible by law for ensuring that every young person in their parish was able to read religious works

\footnotetext{
${ }^{1}$ See, e.g., Henrekson, Jonung, and Stymne (1996, p. 242).

${ }^{2}$ See, e.g., Gårdlund (1942); Lewin (1967).

${ }^{3}$ Sandberg (1979, p. 225).
}

(C) The Author(s) 2022

M. Henrekson and J. Wennström, Dumbing Down, https://doi.org/10.1007/978-3-030-93429-3_1 
and even to write. ${ }^{4}$ Crucially for the success of this educational mission, according to Sandberg, the Swedish clergy was numerous, university trained, and composed to an unusually high degree of descendants of the peasant population it was charged with tutoring. Thus, "the countryside was covered by influential educated persons, perhaps half of them no more than two generations away from peasant status, whose legal duty and ideological convictions required them to assure the universal literacy of their flocks." 5

Another significant factor was Sweden's long history of appreciation for learning. Writing in 1631, the seventeenth-century mathematician Anders Bure observed that the inhabitants of the sparsely populated northern parts of the country were "so fond of letters that, although public schools are very few, nevertheless the literate instruct the others with such enthusiasm that the greatest part of the common people and even the peasants are literate." 6

Sweden was the most literate country in Europe by 1850, with only about a 10 percent rate of adult illiteracy. By this time, formal schooling was also rapidly becoming widespread, implying that the ability to read primarily religious texts and write was accompanied by other knowledge. "By the late 1860 s, at the latest," Sandberg notes, "Sweden had a system of universal elementary education, and the supporting structure of teacher-training institutions, in full operation." 8 Hence, Sandberg argues that when industrialization began, the highly literate and knowledgeable Swedish workforce could seize new opportunities, including technological advancements, with superior skill and determination. In combination with the liberalization of trade and other areas, Sweden's economic development thus "took off like a rocket."

This story is not commonly known because ever since the publication in 1936 of the U.S. journalist Marquis Child's book Sweden: The

\footnotetext{
${ }^{4}$ Several recent studies have established a direct connection between Protestantism and human capital accumulation. See, e.g., Becker and Woessman $(2009,2010)$ and Boppart, Falkinger, and Grossmann (2014).

${ }^{5}$ Sandberg (1979, p. 230).

${ }^{6}$ As quoted in Cipolla $(1969$, p. 54).

${ }^{7}$ Johansson (2009).

${ }^{8}$ Sandberg (1979, p. 230).

${ }^{9}$ Lidström (2015, p. 65$)$.
} 
Middle Way, many foreign observers of Sweden have attributed the country's socially inclusive economic growth to the expansion of the Social Democratic welfare state. ${ }^{10}$ However, as we have suggested here, this analysis overlooks the fundamental causes of Sweden's economic takeoff and expansion in which everyone prospered. ${ }^{11}$ The crucial feature that Sweden exhibited was, in fact, its uniquely large and evenly distributed stock of human capital even before the onset of rapid industrialization and modernization in the late 1860s. Compared to other European countries at the time, Sweden, in this sense, enjoyed a "free ride." 12

In the United States in the late nineteenth and early twentieth centuries, Swedish immigrants also fared better in the job market than other European national groups (as well as native-born white U.S. citizens), ${ }^{13}$ which is strong evidence that Sweden's high human capital levels were, indeed, a decisive factor in the country's sudden economic transformation. The rise of the welfare state in later years ultimately had far less to do with it than is customarily assumed.

If education was the key to growth and the great equalizer in Sweden, then the recent decline of the Swedish educational system should be cause for serious concern about the country's future. We have therefore written this book, which examines the symptoms and causes of this decline as well as the lessons to be drawn from it for Sweden and other similar nations.

After providing a brief overview of the problems with regard to schooling in Sweden, as well as the history we explore in later chapters, we return to the purpose and outline of the book.

\section{Sweden's Educational Crisis}

The heritage of the "impoverished sophisticates," as Sandberg calls the poor but knowledgeable peasantry in Sweden, survived well into the 1950s. ${ }^{14}$ In the general population, particularly in the working and lower

${ }^{10}$ See Childs (1936) and more recently, e.g., Sachs (2006).

${ }^{11}$ As shown by Roine and Waldenström (2008), Swedish income distribution was unusually even as far back as 1920 , i.e., long before the introduction of the redistributive tax and transfer systems.

${ }^{12}$ Sandberg (1979, p. 231).

${ }^{13}$ Sandberg (1979).

${ }^{14}$ See, e.g., Ohrlander (1981). 
middle classes, a strong sense remained that classical knowledge was essential and that the individual's successful mastery of it contributed to a national project of modernization. Schools also generally reflected these values and encouraged students, even those of humbler backgrounds, to pursue careers in science and in professions requiring higher education. However, there were also competing forces at work.

After World War II, the significance of classical knowledge and the traditional instructive pedagogy in Swedish schools was openly questioned by public intellectuals and Social Democratic politicians. It was, in the words of an influential 1948 government report on the future of schooling in Sweden, "increasingly more obvious how seldom acquired knowledge can be considered fixed." 15 The school system of Nazi Germany was also grossly misinterpreted to justify a view that in addition to being obsolete, the teaching of classical knowledge could potentially be subversive to democracy. ${ }^{16}$

It was therefore determined that the main purpose of public education henceforth should be to help students develop the (perceived) general ability of critical thinking, a "democratic" mindset, and the social skills to make friends across class and ability tiers. In line with this new philosophy of education, which was written into national curricula and other governing documents of the school system, it was deemed appropriate to stipulate that the responsibility for schooling should be transferred step by step from the teachers to the students themselves.

Despite a determined effort in the postwar years and the 1960s and 1970 s to radically transform the content and methods of education, the Swedish school system remained rather impervious to change and continued, for a long time, to be relatively good. In fact, when largescale comparative international testing of students' knowledge began in the mid-1990s with the first worldwide TIMSS assessment in mathematics and science in 1995, Swedish students in the final year of secondary education came out on top in science and second in mathematics (the Netherlands was first). Swedish students also outperformed U.S. students across the entire ability distribution.

Moreover, in the first cycle of the OECD's PISA survey, measuring reading ability and mathematics and science proficiency, in 2000, Swedish

${ }^{15}$ SOU 1948:27 (p. 148).

${ }^{16}$ See Heller Sahlgren and Wennström (2020). 
students performed above the international average. It seemed that Sweden's school system was one of the best performing and most equitable and, simultaneously, a model for privatization given that Sweden in the 1990s had implemented the most extensive and liberal voucher system in the world. However, more than a decade of manifestations of deep-seated and overlooked problems followed.

Sweden's performance in international assessments began to steadily deteriorate. For example, in the TIMSS study, Swedish average results fell by 56 points between 1995 and 2011, which was the largest decline among all participating countries. Despite the well-known deficiencies in the U.S. school system, U.S. students now outperformed Swedish students across the entire distribution in mathematics. Perhaps most alarmingly, the decline was relatively greater for students at the bottom of the ability distribution, who had previously fared comparatively well in the Swedish educational system. Mirroring the development observed for the TIMSS, the Swedish PISA results also progressively worsened until a low point was reached in the 2012 survey. The overall score was well below the OECD average, and in each area of PISA, i.e., reading, mathematics, and science, only three OECD countries performed worse than Sweden.

Paradoxically, during the very period in which the TIMSS and PISA results fell sharply, the average merit rating in the final year of elementary school markedly improved. In other words, the worse Swedish students performed in international knowledge assessments, the more their grades improved. This incongruous evolution of test results and grades can be explained only by widespread grade inflation in schools.

There were numerous other signs of trouble. It became clear that Sweden was facing a crisis in the teaching profession. A survey found that only five percent of Swedish teachers deemed that their work was considered prestigious, and barely half of the respondents agreed that they would choose the same occupation again. ${ }^{17}$ In recent years, many teachers have left the profession, and the dropout rate from teachertraining programs has skyrocketed due to dissatisfaction. Moreover, there have been symptoms of a deep malaise among students, including the highest rate of truancy in the OECD and significantly rising rates of mood disorders and ADHD diagnoses.

${ }^{17}$ Swedish National Agency for Education (2014a). 
In sum, something happened in the run-up to the 2000s that negatively affected educational achievement, grading practices, teacher satisfaction, and student well-being. No comprehensive policy response has yet been formulated because there is no consensus among politicians or scholars on how the problems arose, let alone how to resolve them. However, we argue that one potent force, caused by the combination of two seemingly unrelated factors, cuts across all these concerns, offering both an explanation for the challenges to educational quality in Sweden and the prescriptions for addressing them.

\section{The Purpose of the Book}

As we have suggested, Sweden no longer offers an example of a high-quality and equitable school system, as particularly liberal-minded observers of Sweden have tended to believe. Nor does it offer an exemplary model for privatizing education, as advocates of school vouchers and school competition have often claimed. The purpose of this book is to explain these puzzling outcomes.

Our analysis is a novel one. We argue that the origin of Sweden's educational decline is attributable to a phenomenon that we refer to as "post-truth" schooling; that is, an education based on a postmodern social constructivist view of truth and knowledge, the antecedents of which can be found in the education policies of the postwar decades. This view contends that knowledge is socially constructed and fluid, as opposed to being mostly objective and reliable, and therefore is impossible to transfer from teacher to student.

"Post-truth" schooling matured into its current form slowly but steadily. By the early to mid-1990s, it had become the ruling ideological paradigm of the educational system. (For cultural and institutional reasons, explained later in the book, it was not possible to accomplish the desired paradigm shift before that point in time.) These educational ideas were then, in a highly idiosyncratic fashion, combined with the concurrent marketization of education. This combination led to a shift in focus not only in theory, but also in practice, away from classical knowledge in schools. Ultimately, this resulted in a loss of dignity and self-worth for teachers and a lacking sense of direction for students, causing them psychological distress. The chief mechanism was the creation of powerful incentives for both public and independent voucher schools to compete in dimensions other than educational quality. To be clear about our point: 
"post-truth" schooling and the drive to marketize education are two independent forces, but as we will show in subsequent chapters, they are mutually reinforcing and have in tandem created the negative conditions for teachers and students in Sweden. It was through this marriage with the market system that the aim of the postmodern social constructivist view of knowledge to redirect schools from the purpose of teaching in the classical sense could be fully achieved.

Advocates of the current system will no doubt claim that this argument ignores other important and complex processes, and other scholars will propose alternative explanations for the decline in educational quality. However, in our judgment, the stipulated view of knowledge is the most crucial institution of any school system, from which virtually everything else is derived. If there are deficiencies in this regard, there will be ripple effects on the content of curricula and the pedagogy used as well as on the behavior of the various agents involved in the educational system, including students, parents, teachers, school principals, school owners, the central government, and the concerned government agencies. A telling example pertains to the large immigration to Sweden in recent years. It may well be the case that the increase in the share of foreign-born students "mechanically" explains a part of the fall in students' knowledge, as at least one study has suggested, ${ }^{18}$ but in an appropriate institutional setting they would not necessarily have performed worse than Swedish students. ${ }^{19}$ Against this background, a focus on the stipulated view of knowledge must be at the heart of any viable analysis of major weaknesses in school systems. Likewise, a successful reform strategy to improve the quality of education must take this factor prominently into account. In Sweden's case, we argue that a paradigm shift in the stipulated view of knowledge has the potential to yield radical improvement.

Our book adds to previous attempts to study the effects of postmodern social constructivist learning approaches on the quality of education

${ }^{18}$ According to Heller Sahlgren (2015a), 29 percent of the overall decline in the average PISA score from 2000 to 2012 can be explained by the change in student composition.

${ }^{19}$ There is now considerable evidence regarding which teaching methods are efficient, and research shows that by using these methods children from underprivileged environments can also perform well. See, e.g., Chabrier, Cohodes, and Oreopoulos (2016), Fryer and Dobbie (2013), and Woessman (2013). 
and students' knowledge in other societies-for example, the Canadian province of Québec, the United Kingdom, Finland, and France. ${ }^{20}$ However, with its amalgamation of "post-truth" schooling and a firm commitment to voucher schools and school competition, Sweden offers a unique opportunity to study this subject. The consequences of combining institutionalized postmodernism with full-fledged marketization of education have not previously been examined in detail. Our analysis is, therefore, pioneering and shows that this combination negatively affects the quality of education, suggesting that caution is necessary for countries that have a tradition of postmodern social constructivist pedagogy and are now considering implementing or expanding market-based school reforms.

\section{Outline}

Following this introductory chapter, the rest of the book consists of eight chapters. While we do not claim that there has ever been a golden age in Swedish education, we do believe that there was a "silver age" that preceded the present problems and began approximately in the second half of the nineteenth century. This history is presented in Chapter 2.

In Chapter 3, we provide a detailed presentation of what is known about the performance of Swedish students before the first TIMSS assessment and the subsequent decline in international tests.

In Chapter 4, we discuss the emergence of a systemic malaise in the Swedish school system that includes grade inflation, increasing differences in performance between boys and girls, problems of well-being, and a peculiar increase in undemocratic attitudes among students. We also discuss the deterioration of working conditions for teachers and the flight from the teaching profession. Interestingly, it has not been possible to stop this flight despite recent sizable increases in teachers' relative wages.

In Chapter 5, we begin to approach the question of what has gone wrong and why we are seeing these problems in schools. We outline two conflicting and competing visions of knowledge: the classical view and the postmodern social constructivist view. We argue that the classical view is consistent with both modern scientific research and received

${ }^{20}$ See Christodoulou (2014); Haeck, Lefebvre, and Merrigan (2014); Heller Sahlgren (2015b); Hirsch (2016). We return to some of these examples in the final chapter of the book. 
wisdom. However, as the remaining chapters show, Sweden embraced the postmodern social constructivist view.

In Chapter 6, we describe the evolution of the view of knowledge and the ensuing pedagogy within the Swedish school system. We begin in the immediate postwar years and end the chapter in the early 1990s with a discussion of the most radical national curriculum that had been enacted up to then, which consolidated the paradigm of "post-truth" schooling.

In Chapter 7, we show how this educational trend continued into the twenty-first century. We discuss the market of school choice in Sweden and describe how it interacts with postmodern social constructivist ideas. Moreover, we offer a close reading of the national curriculum that was in force at the time of writing (early 2021).

In Chapter 8, we summarize the main findings and consider the effects of "post-truth" schooling in combination with marketized education on students and teachers.

We end the book in Chapter 9 by providing some reflections on the way forward for Sweden and Western education in general.

Open Access This chapter is licensed under the terms of the Creative Commons Attribution 4.0 International License (http://creativecommons.org/licenses/ by $/ 4.0 /)$, which permits use, sharing, adaptation, distribution and reproduction in any medium or format, as long as you give appropriate credit to the original author(s) and the source, provide a link to the Creative Commons license and indicate if changes were made.

The images or other third party material in this chapter are included in the chapter's Creative Commons license, unless indicated otherwise in a credit line to the material. If material is not included in the chapter's Creative Commons license and your intended use is not permitted by statutory regulation or exceeds the permitted use, you will need to obtain permission directly from the copyright holder.

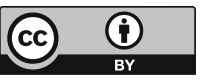

